\title{
International Trade Effects And The Decline In The Union Sector
}

Dwight W. Adamson (E-mail: bill_adamson@sdstate.edu), South Dakota State University

\begin{abstract}
Since the 1960s, U.S. manufacturing has undergone tremendous changes due to international trade and technological convergence. Not all industry sectors have fared equally. High-tech sectors (e.g., aircraft and computers) have maintained a high degree of international competitiveness as evidenced by an increasing export share. Common technology sectors (e.g., autos and steel), conversely, have not as they have experienced a declining export share and increasing import competition. High-tech industries typically employ highly skilled, human capital intensive workers while common technology industries are characterized by unskilled labor with lower levels of human capital. International trade theory suggests that the more skilled high-tech labor force should receive relatively higher wages than the relatively less skilled common-tech sector under international competition. Secondly, the level of unionization in a given industry may or may not have adverse impacts on international competitiveness. Also, unions tend to oppose adoption of new technologies, drive highly educated workers into the nonunion sector, and may adopt end game strategies to maximize current wages at the expense of future economic viability. Consequently, international trade and high-tech industries may have a negative effect on union participation rates.
\end{abstract}

The issues addressed include the effect of international trade and technological comparative advantage on union and nonunion wage levels, and the indirect effect of trade and technology on union participation. This study uses the National Longitudinal Survey (NLS) panel data set. The empirical results suggest that international trade effects wage levels, and high-tech industries appear to have a higher wage distribution after controlling for labor market, product market, and individual characteristics. Furthermore, trade and technology appear to be negatively related to the degree of union density. The secondary effect tends to lower union and nonunion wages, primarily for lessskilled workers. It also may partially explain the trend of increasing income inequality for less-skilled workers and the opposition of unions to free-trade policies.(JEL J3, J5)

\section{Introduction}

$T$

he U.S. labor market has undergone dramatic transformations since the late 1960s (Bound and Johnson, 1992; Freeman and Katz, 1994). First, after 1973, growth in real wages for most Americans dramatically slowed, while it declined outright for many low-skilled workers. Second, income inequality began to increase sometime in the 1970s and accelerated in the 1980s. The widening income inequality is manifested through greater returns to education and skill. Third, U.S. labor unions suffered a precipitous decline in the share of the labor force that it represents. The declining labor movement has been offered as one reason for the increase in income inequality (Freeman, 1993; Freeman and Katz, 1994). That is, wages of blue collar and less-skilled workers tend to be greater if they are represented by a union. Moreover, unions may indirectly increase nonunion blue collar wages through a union threat effect, where nonunion employers essentially "bribe" their work force with higher compensation to deter union organizing fforts. Nonunion wages also may be adversely affected by increased supply caused by a spillover of

Readers with comments or questions are encouraged to contact the author via email. 
workers crowded out of the union sector (Freeman and Medoff, 1984). Thus, if the threat effect dominates, the trend of increasing income inequality in the 1980s may be linked to the precipitous decline in union density over this period. However, if the spillover effect dominates, then the decline in union density will have ameliorated the trend of increasing income inequality.

Concurrent with these changes in the union sector is the rapid increase in international trade. Thus, one possible explanation for the tremendous changes in the labor market is that greater international trade has altered basic labor market institutions such as labor unions and affected the relative demand for various labor occupations. For example, union opposition to the North American Free Trade Agreement (NAFTA) and to GATT exemplifies the staunch resistance to free trade in general by U.S. union leaders. Previous research has found relatively little trade influence on average U.S. wages (e.g., Partridge, 1993; Freeman and Katz, 1991). Never the less, unions oppose trade expansion because it may reduce the likelihood that workers belong to unions. Greater trade can either reduces the likelihood individuals are willing to work in the union sector, or it can reduce the likelihood that unionized employers will expand their work force. In either case, blue-collar workers' wages could be adversely affected by international trade, first, by reducing the union wage differential and, second, by reducing the union density. Thus, international trade, via its effect on unionization, may indirectly enhance rising income inequality.

\section{International Trade And Wages}

Numerous studies have assessed the role of greater foreign trade on U.S. wages. Lawrence and Slaughter (1993), Sachs and Shatz (1994), and Burtless (1995) provide summaries. Overall, there is a theoretical basis to believe that trade is a major cause of the decline in U.S. wage growth and of the increase in income inequality. First, international convergence of European and Japanese industries since World War II, along with more recent convergence of middle-income nations such as Korea, have weakened many U.S. industries (e.g., Johnson and Stafford, 1993). In particular, Johnson and Stafford suggest that when other countries attain the "U.S. level" of technology, greater foreign competition may reduce wages. Borjas and Ramey (1994) contend that trade's influence on durable good manufacturing plays a prominent role in the U.S. labor market. Generally, the arguments of Johnson and Stafford and Borjas and Ramey suggest that greater foreign competition has reduced the availability of quasi-rents for the affected American industries. This reduction in quasi-rents could reduce U.S. wages, especially for blue collar workers, who are also reliant on unions to extract industry rents for their members. Less-skilled blue collar workers also tend to predominate in industries where the technology is more readily available throughout the world (e.g., durable good manufacturing). Their wages may have been especially hurt by international convergence and the resulting increase in foreign competition.

A second reason to expect that international trade may affect the labor market and increase U.S. income inequality is the Heckscher-Ohlin-Samuelson (HOS) trade model. The HOS model implies that greater international trade will increase the returns of a nation's abundant factor relative to the returns of a less abundant factor. That is, the HOS model suggests that skilled labor will fare relatively better than unskilled labor in the U.S.

Empirical studies, however, have not found consistent results on the influence of trade on wages. Several studies have examined the response of average industry wages to changes in industry import and export shares. The typical finding is that changes in trade shares have only a modest impact on wages (e.g., Freeman and Katz, 1991). Similarly, using individual or union contract data, Macpherson and Stewart (1990), Partridge (1993 and 1995), and Blumenfeld and Partridge (1996) also found that trade has had little influence on average earnings but that the actual effect depends on the industry's unionization.

\section{Union Density Effects On Wages}

Adamson and Partridge (1996), using a bivariate probit model to determine workers' likelihood of entering into the union queue and the firms' likelihood of hiring from the union queue, find that international trade creates a substantial uncertainty effect which reduces the probability of union hiring.

There findings suggest that international trade effects, primarily from rising export share and the total level of trade (import plus export share), have had strong negative impacts on union choice. Also, international convergence in 
certain technology sectors, especially capital intensive sectors with a technology common among different countries, have had a negative impact on union choice. These findings suggest that trade may adversely affect unionization rates as well as wage levels. If so, union density as well as wages will be endogenous with respect to trade as well as structural changes due to technological convergence.

Freeman (1992) finds that unionization reduces wage inequality by decreasing the white-collar/blue-collar and college/high-school wage differentials, hence helping to offset the rise in inequality related to education and skill. Furthermore, unions reduce the variation in pay within groups of workers. Freeman and Medoff (1981) argue that greater union density levels act to increase union sector wages by reducing the elasticity of labor demand by limiting the substitutability of nonunion workers. Thus, research suggests that decline in union density in the 1980s may have contributed to the rise in wage inequality. Internationalization of the U.S. economy, while directly impacting wage levels, may have indirectly advanced the inequality trend by adversely affecting union density.

The trend in union density may have also impacted nonunion wages. Declining union density will either positively or negatively affect wages depending on whether the threat or spillover effect dominates. If the threat effect is dominate, nonunion wages are driven up as firms attempt to avoid unionization. Consequently, a decline in the percent of unionization in an industry also lowers nonunion wage and further ameliorates the inequality trend. If the spillover effect is dominate, nonunion wages are driven down by displacement from the union sector, and the decline in union density may actually mitigate the inequality trend.

Rosen (1969) finds evidence of a threat effect using aggregate manufacturing data. Using cross-sectional microdata, Freeman and Medoff (1981), Podgursky (1986), Hirsch and Neufeld (1987), and Dickens and Katz (1987) generally find evidence of the threat effect. However, the positive association between nonunion wages and union density is sensitive to industry characteristics, is statistically insignificant in many cases, and is occasionally negative.

Krueger and Summers (1987) argue that industries with high union densities tend to be highly concentrated and historically paid higher wages. Consequently, the positive association between union density and nonunion wages may reflect unobserved industry characteristics. After adjusting for fixed effects to control for unobserved industry characteristics, Krueger and Summers (1987 and 1988) find no evidence of a threat effect. Martinello and Meng (1992), using Canadian data, find a significant spillover effect. This result was found using a simultaneous equations model with union density both as an exogenous and endogenous variable. Neumark and Wachter (1995) also find evidence of a spillover effect. The negative association between nonunion wages and union density was found using both a fixed effects model and a simultaneous equations model with union density as an endogenous variable.

\section{Empirical Methodology}

Ashenfelter and Johnson (1972) argue that union density and wages are endogenous variables, primarily because wages and unionization are both affected by labor quality as well as industrial structure. ${ }^{1}$ Martinello and Meng (1992) and Neumark and Wachter (1995) both argue that union density is endogenous with respect to nonunion as well as union wages. If both wages and union density are endogenous, then international trade effects will have a direct impact on wages levels and an indirect effect on wages via the trade effects on union density.

Industry composition also changed during the period. Following Lawrence (1984), Partridge (1993), and Blumenfeld and Partridge (1995), we divide manufacturing into four sectors to illustrate these changes. The first is the high-tech sector (HT), which is characterized by high degrees of both human capital and R\&D, as well as short product cycles (e.g., chemicals, aerospace, computers, some industrial machinery). The next two sectors are characterized by a common technology that is readily available throughout the world. One is the labor-intensive common technology sector (CTL) (e.g., apparel, footwear) and the second is the capital-intensive common technology sector (CTK) (e.g., steel, autos). ${ }^{2}$ The final sector is the natural resource-intensive sector (NR), characterized by natural resource intensive

\footnotetext{
${ }^{1}$ The union literature consistently finds that union firms have higher quality labor than nonunion firms. Due to the union wage differential, the higher quality worker queue to enter the union sector. Given the queuing process, union firms select the best workers for employment (e.g., Lee, 1978). ${ }^{2} \mathrm{HOS}$ trade theory provides a rationale for the labor-intensive and capital-intensive distinction.
} 
manufacturing processes (e.g., food processing, lumber, refined oil). ${ }^{3}$ Higher wages in the HT sector relative to the other sectors is consistent with Johnson and Stafford's (1993) international convergence hypothesis. To the extent that the CTL and CTK industries comprise the medium technology industries, changes in relative wages support Johnson and Stafford's hypothesis.

To examine the role of international trade and sectorial changes on wages, a wage equation is augmented with international trade and technology sector variables. The wage model is typically based on micro-level data while the trade and sectorial variables are industrial level data. A typical wage equation specification is:

(1) $\mathrm{LNRWAG}_{\mathrm{i}}=\gamma_{0}+\gamma_{1} \mathrm{XSH}+\gamma_{2} \mathrm{MSH}+\gamma_{3} \mathrm{XUDEN}+\gamma_{4} \mathrm{MUDEN}+\gamma_{5} \mathrm{HT}+\gamma_{6} \mathrm{CTL}+\gamma_{7} \mathrm{CTK}+\gamma_{8} \mathrm{UDEN}+\Gamma \mathrm{CZ}+\beta \mathrm{X}+\varepsilon_{\mathrm{i}}$

The dependent variable $\left(\mathrm{LNRWAG}_{\mathrm{i}}\right.$ ) represents the natural $\log$ of the $\mathrm{i}^{\text {th }}$ individual's real hourly wage. The $\mathrm{Z}$ vector controls for industry related effects. The $\mathrm{X}$ vector contains typical human capital and personal characteristics that used to explain wage rates, and $\varepsilon_{\mathrm{i}}$ is a random error term.

The trade variables consist of the import share (MSH=imports/(imports+output)) and the export share (XSH=exports/output). Union density (UDEN) reflects the percent of unionization in the worker's industry of employment. In addition to import share and export share, some wage equation specifications include an interaction term between union density and import and export share (MUDEN and XUDEN) as independent variables to account for the variation in trade intensity across industries.

Equation (1) is typically estimated by ordinary least squares (OLS). The import and export share coefficients are expected to be negative and positive, respectively. Based on the findings of previous studies (e.g., Macpherson and Stewart, 1990; Partridge, 1993; Blumenfeld and Partridge, 1995), the MUDEN and the XUDEN coefficients are expected to be respectively positive and negative (i.e., the influence of trade share on wages is mitigated in heavily unionized industries).

Dummies for the HT, CTL, and CTK sectors are included to account for differences by sector, where the NR sector is the omitted category. Thus, the HT, CTL, and CTK coefficients are measured relative to the NR sector. Based on the above discussion, the HT coefficient is expected to be greater than the CTL and CTK coefficients. Because sectoral technology effects are controlled for, the trade share variables only account for within-sector trade share effects.

However, following Ashenfelter and Johnson (1972), union density and wages may both be endogenous. LNWAG and UDEN may be jointly determined by human capital characteristics, personal and regional preferences for unions, and international trade. Consequently, estimating equation (1) by OLS can lead to biased and inconsistent parameter estimates. To correct for potential simultaneity bias, we will consider a simultaneous system of equations to estimate both wage and union density effects:

(2a) $\mathrm{LNRWAG}_{\mathrm{i}}=\gamma_{0}+\gamma_{1} \mathrm{XSH}+\gamma_{2} \mathrm{MSH}+\gamma_{3} \mathrm{HT}+\gamma_{4} \mathrm{CTL}+\gamma_{5} \mathrm{CTK}+\gamma_{6} \mathrm{UDEN}+\Gamma \mathrm{CZ}+\beta \mathrm{X}+$

(2b) $\mathrm{UDEN}=\lambda_{0}+\lambda_{1} \mathrm{XSH}+\lambda_{2} \mathrm{MSH}+\lambda_{3} \mathrm{HT}+\lambda_{4} \mathrm{CTL}+\lambda_{5} \mathrm{CTK}+\lambda_{6} \mathrm{LNRWAG}_{\mathrm{i}}+\Lambda \mathrm{Z}+\Phi \mathrm{X}+\mu_{\mathrm{i}}$

Equation (2a) specifies UDEN as endogenous, and the MUDEN and XUDEN interaction terms are dropped from the wage equation. Equation (2b) explains union density of a given industry as a function of import and export share, the technology sectoral dummy variables, the LNRWAG for the $\mathrm{i}^{\text {th }}$ individual, the $\mathrm{Z}$ vector of industry characteristics, and the $X$ vector of human capital and personal characteristics. The system of equations ( $2 a$ ) and (2b) are estimated by three-stage least squares (3SLS). ${ }^{4}$ To investigate the effect of union density and international trade on the

${ }^{3}$ For the United States, Arndt and Bouton (1987) show that there are significantly different product market and technological characteristics between these four sectors, and Partridge (1993) finds that union and nonunion wage patterns vary across these three sectors. For instance, the HT sector appears to possess greater product market power (e.g., greater four-firm product market concentrations, trade surpluses, and value added per worker). In an international context, especially since the 1970s, the CTL and CTK sectors have less product market power (e.g., large trade deficits). ${ }^{4}$ Estimation of this system of equations were more efficient using 3SLS, and clearly superior to estimates obtained using two-stage least squares (2SLS). 
individual union and nonunion sector, wage and union density equations ( $2 a$ ) and ( $2 b$ ) as well as the OLS wage equation (1) will be estimated separately for both sectors.

\section{A. Data}

Data from the National Longitudinal Survey of Young Men from 1978-1980 is combined with three-digit industry data for the empirical analysis, resulting in a sample of 734 workers. The advantage of this time period is that the U.S. trade balance was approximately zero and the wild currency fluctuations of the 1980s had not affected manufacturing, which implies that we are considering a period that was approximately in equilibrium. Moreover, this period is prior to the dramatic declines in unionization and the tremendous changes in management attitudes towards unions that are attributed to the 1980s and 1990s. Hence, we do not confound these other effects with trade's influence.

The variables in the vector $\mathrm{X}$ for the wage equation follow conventional specifications. The human capital and individual characteristics in X that are used to explain LNRWAG include years of completed education (ED) and dummies for collective bargaining coverage (UNION), part-time employment (PT), marriage (MAR), health problems in the last year that affected the individual's work (HEA), and nonwhite racial status (MINORITY). Worker's tenure (TEN) and its square (TENSQ) as well as potential work experience (EXP) along with its square (EXPSQ) are also added. Occupational dummy variables represent professional and technical (PROF), managers (MANAG), clerical (CLER), sales (SALES), craftsmen (CRAFT), operatives (OPER), and household and service workers (SERV); laborers are the omitted category. Finally, the models control for the regional differences in labor markets and attitudes towards unions which are controlled for with a Southern residence (SOUTH) dummy. Similarly, dummies for residence in a metropolitan area (URBAN) and the unemployment rate multiplied by 10 are also included.

The exact specification of the UDEN equation is less certain. It is typically argued that, due to selectivity from the union queue, union sector firms have better labor quality in their work force than similar nonunion firms (Lee, 1978). Conversely, DeFreitas (1993) and Abowd and Farber (1982) find that less-skilled workers with lower level of educational attainment desire union employment and are more likely to enter the union queue. The human capital characteristics in X that are used to explain UDEN include ED, EXP, and TEN. Personal characteristics used to control for individual and regional taste for union sector employment include MINORITY, UNION, SOUTH, URBAN, HEA, and PT.

The trade variables are from U.S. Department of Commerce data. Both the LNRWAG and UDEN model specifications contain several industry variables in the $Z$ vector which are included to measure industry effects on wages and union density. First, an international trade adjusted concentration ratio accounts for domestic product market power adjusted for imports and exports (CR4INT). ${ }^{5}$ Industry dummy variables are included for durable goods and nondurable goods where the equipment, intermediate goods, and automobile producing industries are the omitted category (Lawrence, 1984). A steel dummy variable is also included. The three-year percent change in real industry output (RCHS) helps control for "temporary" shifts in the labor demand curve. (Freeman and Katz (1991) report that three-year changes seem to be the best choice.) For example, if domestic demand is growing rapidly, imports may increase even though the domestic industry is healthy, where RCHS accounts for this effect.

\section{B. Empirical Results}

Tables I and II give the regression results for the 1978 and 1980 wage models, respectively. Since the data have been "stretched" by combining the micro-data with industrial data, the parameter coefficients and the t-statistics should be interpreted cautiously. ${ }^{6}$ Column (1) shows the descriptive statistics for the specific variables in each model. Column (2)

\footnotetext{
${ }^{5}$ Let $\mathrm{S}, \mathrm{X}$, and $\mathrm{M}$ equal domestic output, exports, and imports. Then CR4INT equals:

$\mathrm{CR} 4 \mathrm{INT}=\mathrm{CR} 4 \cong((\mathrm{S}-\mathrm{X}) /(\mathrm{S}+\mathrm{M}-\mathrm{X}))$. Industry output is derived from U.S. Bureau of the Census $(\mathrm{a}$ and $\mathrm{b})$ and industry CR4 is from U.S. Bureau of the Census (b) and Weiss and Pascoe (1986).

${ }^{6}$ There are two offsetting considerations when using aggregate industry level data in a micro data set. First, Greenberg et al (1989) argue that data stretching of this type leads to an errors-in-variables problem which leads to parameter estimates that are biased towards zero. Since the estimates are smaller than the true parameter values, the results should be interpreted as a lower bound estimate. Second, Moulton (1990) shows that if the random disturbances within variable groups are correlated, then the standard errors are downward biased and the t-statistics are inflated.
} 
reports OLS regression results for the LNRWAG model with the MUDEN and XUDEN indirect effects. Both interaction terms are significant and have the expected a priori signs (i.e., the negative wage effect of a rising MSH is mitigated by heavily unionized industries, and the postive wage effect of a rising XSH is not realized by unionized workers). The 1978 estimates for the direct effect of MSH and XSH on wages are opposite of the anticipated sign, but only the MSH is significant. The positive, significant UDEN estimate suggests that union density induces a threat effect, rasing wages $.26 \%$ for each percentage increase in UDEN. ${ }^{7}$ The HT sectorial variable is significant and implies that high-tech industries have the expected positive impact on wages, relative to the natural resources sector. The common-tech sectors also have a positive influence on wages. In the 1980 model, none of the estimated direct or indirect trade share effects are significant, and UDEN is no longer significant.

Based on the 1980 results, the OLS wage specification with the MUDEN and XUDEN interaction terms may be subject to simultaneity bias. Endogeneity of the UDEN variable is tested using a Hausman specification test. ${ }^{8}$ The null hypothesis of no endogeneity can be rejected at the $95 \%$ level in both the 1978 and 1980 wage model. To control for simultaneity bias, LNRWAG and UDEN are estimated by 3SLS. The results are reported in columns (3) and (4), respectively. With respect to the direct effects from international trade, the 1978 coefficient for MSH in Table 1 is significant and has a positive impact on wages, while XSH has a negative wage effect. This is contrary to a priori expectations. UDEN is also significant and the estimated positive effect on wages is larger than in the OLS estimates (suggesting that the UDEN OLS estimate is biased downward). The 3SLS estimates for UDEN implies a fairly strong threat effect, raising wages $1.26 \%$ per percentage change in union density. The HT sector now has a negative effect on wages, contrary to a priori arguments. The sign of the CTL sector also changes from positive to negative. This result would not be surprising if technological convergence is occurring. ${ }^{9}$

In column 4, the UDEN parameter estimates reflect the effect of MSH, XSH, and the sectorial dummy variables on union density. XSH is strongly negative, suggesting that at the mean, XSH lowers union density by $8.65 \%$ which, in turn, indirectly lowers wages by $10.9 \%$. The XSH result implies that unionization rates are seriously impacted by a rising export share, perhaps due to international wage competition. The MSH is associated with a $5.8 \%$ higher union density and indirectly increases wages by $7.0 \%$, offsetting the negative export effect on union density. The HT, CTK, and CTL sectorial dummy variables all have a significant, negative effect on UDEN. Thus, the indirect effect of the technology sectors on wages is to lower union density $9.5 \%$ which, in turn, lowers wages by $12.3 \%$, ceteris paribus. The CTL and CTK sectors also reduce union density by $16.0 \%$ and $4.4 \%$, respectively and thus, wages by $20.1 \%$ and $5.5 \%$. The net wage effect of trade and technology sectors suggest that export sensitive industry wages in 1978 are negatively impacted by the direct effect of XSH on wages and this downward effect in further enhanced by the reduction in union density. This implies that export sensitive industries are probably being subjected to international convergence. In import sensitive industries, however, wages are enhanced by the MSH direct effect and indirect effect on union density and is lowered only by any HT, CTL, or CTK sectorial effect. This minimal net impact of imports on wages may result from union endgame effects in import sensitive industries, or perhaps an efficiency wage paid to retain quality workers.

The 3SLS parameter estimates for the 1980 wage model (column 3, Table II) indicate that the XSH is significant and has the anticipated positive direct effect on wages (at the mean, XSH raises wages by .69\% for each $1 \%$ increase in $\mathrm{XSH}$ ). MSH has the a priori sign but lacks significance. Moreover, HT, CTK, and CTL all have a significant and positive effect on wages (relative to the NR sector), resulting in a $26.4 \%, 7.8 \%$, and $14.9 \%$ increase in wages, respectively. The UDEN estimate again suggests that union density is endogenous. The estimate is significant and about six times the magnitude of the OLS estimate.

The UDEN parameter estimates in column (4) show the indirect effects on wages from the trade shares and technology sectors. XSH and MSH estimates are both significant. At the mean, XSH lowers union density by 3.9\%

\footnotetext{
${ }^{7}$ The percentage effect on the hourly wage rate is calculated by $\left(e^{\gamma}-1\right) \cdot 100 \cdot x$, where $\gamma$ is the parameter estimate of the effect of a specific variable $x$ on the natural logarithm of the hourly wage.

${ }^{8}$ This particular test is based on Spencer and Berk (1981). The probability of rejecting the null hypothesis of no endogeneity is $\alpha=.0285$ in the 1978 model and $\alpha=.0362$ in the 1980 model.

${ }^{9}$ The 3SLS estimates are very sensitive to the specification of the LNRWAG and UDEN models.
} 
which lowers wages by $4.7 \%$. Thus, the net effect of XSH on wages is a $1.5 \%$ increase (Table 4), after accounting for the positive direct effect of XSH on wages of $6.2 \%$ and the negative indirect effect of XSH on union density. Imports, on the other hand, have an apparent negative effect on wages which is offset by a positive effect on union density and wages. HT, CTK, and CTL, however, all lower union density relative to the NR sector. The reduction in union density causes wages to decline, in turn, by $22.3 \%, 7.1 \%$, and $7.8 \%$ in the HT, CTK, and CTL sectors, respectively. The net change in wages (indirect plus direct effects) is a $4.07 \%$ decrease in HT wages, a negligible $.8 \%$ increase in CTK wages, and a negligible $-.3 \%$ wage decrease in the CTL sector. Thus, much of the direct effect of international trade and technological convergence on manufacturing wages is being offset by an indirect effect related to changes union density, causing the net impact to have only a small, benign effect on wages.

The sample was split into union and nonunion sectors and the same OLS and 3SLS wage models were estimated to determine if the effects of international trade and technological convergence differ across union and nonunion sectors. Table III contains the results for the union sector. The OLS results are similar are similar to the full model with the exception that MSH has a large, negative effect on union wages. The 3SLS estimates are similar to the full sample wage model with the exception that MSH and XSH no longer have a significant direct effect on union wages, while the HT and CTL technological sectors have positive direct wage effects in both 1978 and 1980. In the UDEN model, the HT and CTL sectors have strong negative effects on union density, and MSH has a positive effect on UDEN in 1980. The results suggest that positive direct union wage effect of the HT and CTL sectors offset the negative indirect union wage effects from declining union density. Thus, the union sector effects from trade and technological convergence are similar to the benign effects in the full model.

Table IV contains the results for the nonunion sector. The OLS estimates generally have no explanatory power. With the exception of MSH in 1978, the 3SLS estimates suggest that there is no consistent positive direct effect on wage to offset the negative indirect impact on nonunion wages from the persistent reduction in union density caused by the technological sectors. Nonunion wages are lowered by $9.38 \%$ in the HT sector, $5.12 \%$ in the CTL sector, and $4.7 \%$ in the CTK sector. XSH and MSH have offsetting effects on union density, causing their indirect wage effects to offset. The results suggest that nonunion wages, rather than union wages, are impacted over time by falling union density levels which diminishes the threat effect on nonunion wages.

The nonunion results suggest that the declining levels of union participation experienced by the U.S. economy over the 1980s has contributed to the increasing income inequality trend over this period, primarily by lowering nonunion wages, as union sector wages are not severely impacted by the decline in union density. Thus, the income inequalities induced by few less-educated, blue collar workers in union job is further amplified by the decline in the threat effect on nonunion wages as industrial union density levels decline.

\section{Conclusion}

This paper examines how international factors have affected manufacturing wage levels and union density. We present a simultaneous equations model that distinguishes between the direct and indirect effects on wages of trade shares and technological factors which influence international competitiveness. The results suggest that the percent of unionization has positive effects on both union and nonunion wages. Overall, we found evidence that wages and union density are jointly endogenous and the appropriate estimation procedure requires 3SLS, rather the traditional approach of estimating wages and indirect union density effects as an OLS reduced form. Using OLS, the union density parameter estimate is biased downward and is inconsistent.

The results suggest that import and export share as well as HT, CTK, and CTL sectorial dummy variables generally have a significant direct effect on wages. However, the sign and magnitude of the effects tend to vary over time. This may reflect labor market dynamics or instability in the parameter estimates. Secondly, export share and the technology sectorial variables have a consistently negative effect on union density, which in turn reduces wages. Import share, interestingly, tends to have a positive effect on union density. The direct trade and technology effects on wages are typically offset by the indirect effects which are transmitted to wages through union density changes. Consequently, the net effect of import and export share and the technology sector in the full-sample wage model is typically small and mixed with respect to the sign of the wage effect. This result also holds for union sector wage estimates. In the nonunion 
sector, the direct wage effect do not appear to offset the indirect decline in wages caused by declining union density. Thus, nonunion wages, via the threat effect, are more severely impacted by declining union participation than union sector wages.

\section{References}

1. Abowd, J. and H. Farber, "Job Queues and the Union Status of Workers," Industrial and Labor Relations Review, April 1982 (35), pp. 354-376.

2. Adamson, Dwight W. and Mark D. Partridge, "The Influence of International Trade on Union Firm Hiring and Worker Union Choice," in Globalization and Development: Growth, Equality and Sustainability (Edited by Satya Dev Gupta and Nanda K. Choudhry), Hingham, MA: Kluwer Academic Publishers, December 1996.

3. Arndt, S.W. and L. Bouton, Competitiveness: The United States in World Trade, Washington D.C.: American Free Enterprise Institute, 1987.

4. Ashenfelter, Orley and George E. Johnson, "Unionism, Relative Wages, and Labor Quality in U.S. Manufacturing Industries," International Economic Review, October 1972 (3), pp. 488-507.

5. Blumenfeld, Stephen and Mark D. Partridge, "The Long-Run and Short-Run Effects of Global Competition on U.S. Union Wages. Journal of Labor Research, Winter 1996 (17), pp. 149-171.

6. Borjas, George J. and Valerie A. Ramey, "Time-Series Evidence on the Sources and Trends in Wage Inequality," American Economic Review, May 1994 (84), pp. 10-16.

7. Bound, John and George Johnson, "Changes in the Structure of Wages in the 1980s: An Evaluation of Alternative Explanations," American Economic Review, June 1992 (82), pp. 371-392.

8. Burtless, Gary, "International Trade and the Rise in Earnings Inequality," Journal of Economic Literature, June 1995 (33), pp. 800-816.

9. DeFreitas, Gregory, "Unionization Among Racial and Ethnic Minorities," Industrial and Labor Relations Review, January 1993 (46), pp. 284-301.

10. Dickens, William T. and Lawrence F. Katz, "Inter-industry Wage Differences and Industry Characteristics," In Kevin Lang and Jonathan Leonard, eds. Unemployment and the Structure of Labor Markets, New York: Basil Blackwell, pp. 48-89.

11. Freeman, Richard, "How Much has De-Unionization Contributed to the Rise in Male Earnings Inequality," in Uneven Tides, Rising Inequality in America (edited by S. Danziger and P. Gottschalk), New York: Russell Sage Foundation, 1993, pp. pp. 133-163.

12. _ _ and L. Katz, "Industrial Wage and Employment Determination in an Open Economy," in Immigration, Trade, and the Labor Market, (Edited by J. Abowd and R. Freeman), Chicago: University of Chicago Press, 1991, pp. 235-260.

13. , "Rising Wage Inequality: The United States Vs. Other Advanced Countries," in Working Under Different Rules (edited by R. Freeman), New York: Russell Sage Foundation, 1994, pp. 29-62.

14. Freeman, R. B. and J. Medoff, What Do Unions Do? New York: Basic Books, 1984.

15. _ _ _ _ "The Impact of Percentage Organized on Union and Nonunion Wages," Review of Economics and Statistics, November 1981 (4), pp. 561-72.

16. Greenberg, E., W. Pollard, and W. Alpert, "Statistical Properties of Data Stretching," Journal of Applied Econometrics, October-December 1989 (4), pp. 383-391.

17. Hirsch, Barry T. and John L. Neufeld, "Nominal and Real Union Wage Differentials and the Effects of Industry and SMSA Density," Journal of Human Resources, Winter 1987 (22), pp. 138-148.

18. Krueger, Alan B. and Lawrence H. Summers, "Efficiency Wages and the Inter- Industry Wage Structure," Econometrica, March 1988 (56), pp. 259-294.

19. __ _Reflections on the Inter-industry Wage Structure," In Kevin Lang and Jonathan Leonard, eds. Unemployment and the Structure of Labor Markets, New York: Basil Blackwell, pp. 259-594.

20. Johnson, George E. and Frank P. Stafford, "International Competition and Real Wages," American Economic Review, May 1993 (83), pp. 127-130.

21. Lawrence, Robert Z., Can America Compete? Washington, D.C.: Brookings Institution, 1984.

22. __ and Mathew J. Slaughter, "International Trade and American Wages in the 1980s: Giant Sucking Sound or Small Hiccup?" Brookings Papers on Economic Activity, Microeconomics (2), 1993, pp. 161-226.

23. Lee, L., "Unionism and Wage Rates," International Economic Review, June 1978 (19), pp. $415-433$. 
24. Macpherson, D. A. and J. B. Stewart, "The Effects of International Trade on Union and Nonunion Wages," Industrial and Labor Relations Review, April 1990 (43), pp. 434-446.

25. Martinello, Felice and Ronald Meng, "Effects of Labor Legislation and Industry Characteristics on Union Coverage," Industrial and Labor Relations Review, October 1992 (46), pp 176-90.

26. Moulton, Brent R., "An Illustration of a Pitfall in Estimating the Effects of Aggregate Variables on Micro Units," Review of Economics and Statistics, March 1990 (72), pp. 334-338.

27. Newmark, David and Michael L. Wachter, "Union Effects on Nonunion Wages: Evidence from Panel Data on Industries and Cities," Industrial and Labor Relations Review, October 1995 (49), pp 20-38.

28. Partridge, Mark D., "Technology, International Competitiveness, and Union Behavior," Journal of Labor Research, Spring 1993 (14), pp. 131-149.

$29 . \quad$ _ _ _International Trade and the U.S. Wage Structure," Journal of Economics and Finance, Summer 1995 (19), pp. 123-144.

30. Podgursky, Michael, "Unions, Establishment Size, and Intra-Industry Threat Effects," Industrial and Labor Relations Review, January 1986 (39), pp 277-84.

31. Rosen, Sherwin, "Trade Union Power, Threat Effects, and the Extent of Organization" Review of Economic Studies, January 1969 (39), pp. 185-96.

32. Sachs, Jeffrey D. and Howard J. Shatz, "Trade and Jobs in U.S. Manufacturing," Brookings Papers on Economic Activity, 1, 1994, pp. 1-84.

33. Spencer, D. E. and K. N. Berk, "A Limited Information Specification Test," Econometrica, July 1994 (49), pp. 1079-1085.

34. U.S. Bureau of the Census, Annual Survey of Manufactures, Washington, D.C.: Government Printing Office, various years.

35. U.S. Bureau of the Census, Census of Manufacturing, Washington, D.C.: Government Printing Office, various years.

36. U.S. Department of Commerce, U.S. Commodity Exports and Imports as Related to Output, Washington, D.C.: Government Printing Office, various years.

37. U.S. Department of Labor, Employment and Earnings, Government Printing Office. various January issues.

38. Weiss, Leonard W. and George A. Pascoe, Adjusted Concentration Ratios in Manufacturing, 1972 and 1977, Statistical Report of the Bureau of Economics to the Federal Trade Commission. Washington, D.C., 1986. 
TABLE 1: 1978 Mean Values And Parameter Estimates ${ }^{a}$

\begin{tabular}{|c|c|c|c|c|}
\hline & $\begin{array}{c}\text { (1) } \\
\text { MEANS } \\
\text { (STAND. DEV) } \\
\end{array}$ & $\begin{array}{c}\text { (2) } \\
\text { OLS WAGE EQ. w/ UDEN } \\
\text { and XUDEN }\end{array}$ & $\begin{array}{c}\text { (3) } \\
\text { 3SLS WAGE } \\
\text { EQUATION } \\
\end{array}$ & $\begin{array}{c}\text { (4) } \\
\text { 3SLS UDEN } \\
\text { EQUATION }\end{array}$ \\
\hline \multicolumn{5}{|l|}{ Exog. Var: } \\
\hline TEN78 & $72.76(53.8)$ & $0.0032(3.84)^{\mathrm{I}}$ & $0.0036(4.26)^{\mathrm{I}}$ & $0.0376(4.45)^{\mathrm{I}}$ \\
\hline TENSQ78 & 8185 (9870) & $-.00001(2.37)^{\mathrm{H}}$ & $-.00001(2.64)^{\mathrm{I}}$ & \\
\hline EXP78 & $11.55(4.12)$ & 0.0195 (1.19) & $0.0241(1.37)$ & $-.1807(0.33)$ \\
\hline EXPSQ78 & $150.3(104.8)$ & $-.0003(0.48)$ & $-.0005(0.69)$ & \\
\hline ED78 & $12.78(2.50)$ & $0.0589(6.36)^{\mathrm{I}}$ & $0.0625(6.94)^{\mathrm{I}}$ & 0.4805 (1.40) \\
\hline UNION78 & $0.41(0.49)$ & $0.1415(4.48)^{\mathrm{I}}$ & $0.1971(5.49)^{\mathrm{I}}$ & $3.368(3.39)^{\mathrm{H}}$ \\
\hline MAR78 & $0.78(0.41)$ & $0.0535(4.18)^{\mathrm{H}}$ & $0.0564(4.89)^{\mathrm{I}}$ & \\
\hline MINOR78 & $0.26(0.44)$ & $-.2148(5.76)^{\mathrm{H}}$ & $-.2443(6.44)^{I}$ & $-2.254(1.76)^{\prime}$ \\
\hline HEA78 & $0.08(0.27)$ & $-.1884(2.08)^{\mathrm{I}}$ & $-.1972(3.55)^{\mathrm{I}}$ & $-.8740(0.49)$ \\
\hline UNEM78 & $57.05(32.6)$ & 0.0005 (1.02) & $.0002(0.46)$ & $-.0177(1.32)$ \\
\hline SOUTH78 & $0.39(0.49)$ & $-.1069(3.42)^{\mathrm{I}}$ & $-.1040(3.09)^{\mathrm{H}}$ & $-.0273(0.37)$ \\
\hline URBAN78 & $0.68(0.47)$ & $0.1642(2.45)^{\mathrm{I}}$ & $0.1618(2.54)^{\mathrm{I}}$ & $0.8402(0.37)$ \\
\hline PT78 & $0.008(0.09)$ & $-.2430(1.05)$ & $-.1773(1.29)$ & $1.2238(0.30)$ \\
\hline PROF78 & $0.13(0.47)$ & $0.1369(1.79)^{\prime}$ & $0.2218(2.72)^{\mathrm{I}}$ & $5.6912(2.36)^{\mathrm{H}}$ \\
\hline MANAG78 & $0.09(0.29)$ & $0.0860(1.14)$ & $0.1233(1.57)$ & $2.2010(0.93)$ \\
\hline CLER78 & $0.06(0.24)$ & $-.1438(1.88)^{\prime}$ & $-.1162(1.38)$ & $0.7743(0.31)$ \\
\hline SALES78 & $0.04(0.21)$ & $0.1146(1.17)$ & $0.0838(0.93)$ & $-1.841(0.68)$ \\
\hline CRAFT78 & $0.26(0.44)$ & $0.0136(0.24)$ & $0.0035(0.05)$ & $-.7357(0.38)$ \\
\hline OPER78 & $0.35(0.40)$ & $-.0966(1.78)$ & $-.0733(1.17)$ & $0.7892(0.42)$ \\
\hline SERV78 & $0.008(0.09)$ & $-.1938(10.98)$ & -.1952 (19.7) & $-.9152(1.29)$ \\
\hline DUR78 & $0.04(0.14)$ & $-.0508(0.64)$ & $0.0868(1.03)$ & $-1.641(0.65)$ \\
\hline NOND78 & $0.14(0.34)$ & $-.0616(1.22)$ & $-.0759(1.39)$ & $-1.873(1.14)$ \\
\hline STEEL78 & $0.07(0.25)$ & $-.2729(3.24)^{\mathrm{I}}$ & $0.2800(2.65)^{\mathrm{H}}$ & $23.58(11.9)^{\mathrm{I}}$ \\
\hline RCHS78 & $20.56(12.7)$ & $-.0006(0.40)$ & $0.0001(0.07)$ & $-.0380(0.85)$ \\
\hline CR4INT78 & 36.83 (11.9) & $0.0038(2.72)^{\mathrm{H}}$ & $0.0029(1.94)^{\mathrm{H}}$ & $-.5835(1.24)$ \\
\hline NR78 & $0.24(0.43)$ & & & \\
\hline CTL78 & $0.19(0.37)$ & $0.1322(1.98)^{\mathrm{I}}$ & $-.1724(1.86)^{\prime}$ & $-15.99(7.25)^{\mathrm{I}}$ \\
\hline CTK78 & $0.27(0.44)$ & $0.0768(1.83)^{\prime}$ & $-.0141(0.30)$ & $-4.404(3.17)^{\mathrm{I}}$ \\
\hline HT78 & $0.30(0.43)$ & $0.1218(2.04)^{\mathrm{I}}$ & $-.1173(1.63)^{\prime}$ & $-9.750(5.91)^{\mathrm{I}}$ \\
\hline MSH78 & $0.08(0.06)$ & $-.7047(0.95)$ & $1.485(3.43)^{\mathrm{H}}$ & $69.78(6.23)^{\mathrm{I}}$ \\
\hline XSH78 & $0.08(0.06)$ & $1.0441(1.76)^{\prime}$ & $-1.57(2.92)^{\mathrm{H}}$ & $-108.1(9.13)^{\mathrm{I}}$ \\
\hline MUDEN78 & $2.69(2.78)$ & $0.0333(1.73)^{\prime}$ & & \\
\hline XUDEN78 & $1.97(1.52)$ & $-.0594(2.84)^{\mathrm{H}}$ & & \\
\hline \multicolumn{5}{|l|}{ Endog. Var: } \\
\hline LNRWAG78 & $6.83(0.42)$ & & & $-4.0944(1.22)$ \\
\hline UDEN78 & $33.9(16.6)$ & $.0026(2.45)^{\mathrm{H}}$ & $.0125(3.59)^{\mathrm{H}}$ & \\
\hline $\begin{array}{l}\text { Number of } \\
\text { Observations }\end{array}$ & 734 & & & \\
\hline $\mathbf{R}^{2}$ & & 0.55 & 0.45 & 0.56 \\
\hline
\end{tabular}

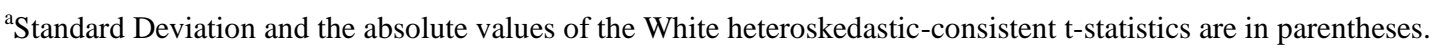

${ }^{\mathrm{I}}$ Significant at a $99 \%$ level.

${ }^{\mathrm{H}}$ Significant at a $95 \%$ level.

'Significant at a $90 \%$ level. 
TABLE 2: 1980 Mean Values And Parameter Estimates ${ }^{a}$

\begin{tabular}{|c|c|c|c|c|}
\hline & $\begin{array}{c}\text { (1) } \\
\text { MEANS } \\
\text { (STAND. DEV) } \\
\end{array}$ & $\begin{array}{c}\text { (2) } \\
\text { OLS WAGE EQ. w/ } \\
\text { UDEN and XUDEN }\end{array}$ & $\begin{array}{c}\text { (3) } \\
\text { 3SLS WAGE } \\
\text { EQUATION } \\
\end{array}$ & $\begin{array}{c}\text { (4) } \\
\text { 3SLS UDEN } \\
\text { EQUATION } \\
\end{array}$ \\
\hline \multicolumn{5}{|l|}{ Exog. Var: } \\
\hline TEN80 & $87.54(59.0)$ & $0.0029(2.84)^{\mathrm{I}}$ & $0.0018(2.74)^{\mathrm{I}}$ & $-.0995(1.23)$ \\
\hline TENSQ80 & $11140(12101)$ & $-.00001(1.40)$ & $-.00001(0.99)$ & \\
\hline EXP80 & $13.42(4.40)$ & $0.0063(0.40)$ & $0.0077(0.51)$ & $-.4659(0.43)$ \\
\hline EXPSQ80 & $199.4(123.3)$ & $-.0002(0.40)$ & $-.0002(0.43)$ & \\
\hline ED80 & $12.88(2.59)$ & $0.0621(8.99)^{\mathrm{I}}$ & $0.0612(8.90)^{\mathrm{I}}$ & $-3.657(1.75)^{\prime}$ \\
\hline UNION80 & $0.40(0.49)$ & $0.0957(3.49)^{\mathrm{I}}$ & $0.0604(2.24)^{\mathrm{H}}$ & $-2.624(0.67)$ \\
\hline MAR80 & $0.78(0.60)$ & $0.0513(1.97)^{\mathrm{I}}$ & $0.0616(2.45)^{\mathrm{H}}$ & \\
\hline MINOR80 & $0.26(0.44)$ & $-.1318(4.72)^{\mathrm{H}}$ & $-.1223(4.24)^{\mathrm{I}}$ & 7.106 (1.38) \\
\hline HEA80 & $0.08(0.27)$ & $-.1002(2.08)^{I}$ & $-.0946(1.91)^{\mathrm{H}}$ & $5.502(1.15)$ \\
\hline UNEM80 & $63.05(35.5)$ & $0.0012(3.71)^{\mathrm{H}}$ & $0.0013(3.87)^{\mathrm{I}}$ & $-.7833(1.78)^{\prime}$ \\
\hline SOUTH80 & $0.38(0.49)$ & $-.0923(3.51)^{\mathrm{I}}$ & $-.1167(4.46)^{\mathrm{I}}$ & $7.624(2.14)^{\mathrm{H}}$ \\
\hline URBAN80 & $0.67(0.47)$ & $0.1137(7.59)^{\mathrm{I}}$ & $0.1134(8.07)^{\mathrm{I}}$ & $1.187(2.07)^{\mathrm{H}}$ \\
\hline PT80 & $0.003(0.05)$ & $-.1871(1.77)^{\mathrm{H}}$ & $-.1652(0.79)$ & $9.718(0.60)$ \\
\hline PROF80 & $0.13(0.33)$ & $0.1110(2.78)^{\mathrm{I}}$ & $0.0854(1.98)^{\mathrm{H}}$ & $-4.330(0.78)$ \\
\hline MANAG80 & $0.11(0.31)$ & $0.2578(5.25)^{\mathrm{I}}$ & $0.2414(5.63)^{\mathrm{I}}$ & $-13.96(1.41)$ \\
\hline CLER80 & $0.07(0.25)$ & $-.1755(4.08)^{\mathrm{I}}$ & $-.2109(4.20)^{\mathrm{I}}$ & $13.52(2.28)^{\mathrm{H}}$ \\
\hline SALES80 & $0.03(0.16)$ & 0.1309 (1.39) & $0.1795(2.60)^{\mathrm{I}}$ & $-12.18(1.80)^{\prime}$ \\
\hline CRAFT80 & $0.25(0.43)$ & $-.0454(2.04)^{\mathrm{H}}$ & $0.0180(0.41)$ & $0.504(0.27)$ \\
\hline OPER80 & $0.37(0.48)$ & $-.0581(8.08)^{\mathrm{I}}$ & $-.1486(8.00)^{\mathrm{I}}$ & $8.615(1.84)^{\prime}$ \\
\hline SERV80 & $0.004(0.06)$ & $-.1589(1.56)$ & $-.1933(0.93)$ & $12.77(0.81)$ \\
\hline DUR80 & $0.04(0.19)$ & $-.0916(1.22)$ & $0.0605(0.91)$ & $2.626(0.45)$ \\
\hline NOND80 & $0.14(0.34)$ & $-.1028(2.26)^{\mathrm{H}}$ & $-.0432(1.04)$ & $0.952(1.14)$ \\
\hline STEEL80 & $0.07(0.25)$ & $-.0329(0.50)$ & $-.2217(3.62)^{\mathrm{I}}$ & $19.42(4.70)^{\mathrm{I}}$ \\
\hline RCHS80 & $1.98(14.3)$ & $-.0007(0.53)$ & $0.0003(2.29)^{\mathrm{H}}$ & $-.2173(2.73)^{I}$ \\
\hline CR4INT80 & $36.4(12.4)$ & $0.0009(1.04)$ & $-.0027(2.85)^{\mathrm{I}}$ & $0.2612(3.57)^{I}$ \\
\hline NR80 & $0.30(0.43)$ & & & \\
\hline CTL80 & $0.19(0.37)$ & $0.0070(0.11)$ & $0.1388(2.26)^{\mathrm{H}}$ & $-12.13(2.84)^{I}$ \\
\hline CTK80 & $0.27(0.44)$ & $0.0288(0.70)$ & $0.0754(2.04)^{\mathrm{H}}$ & $-5.836(2.27)^{\mathrm{H}}$ \\
\hline HT80 & $0.24(0.40)$ & $0.0825(1.50)$ & $0.2339(4.49)^{\mathrm{I}}$ & $-18.46(5.36)^{\mathrm{I}}$ \\
\hline MSH80 & $0.09(0.07)$ & $-.3436(0.49)$ & $-.3413(1.25)$ & $34.48(1.67)^{\prime}$ \\
\hline XSH80 & $0.09(0.07)$ & $0.4194(0.99)$ & $0.5220(2.92)^{\mathrm{H}}$ & $-43.60(2.21)^{\mathrm{H}}$ \\
\hline MUDEN80 & $2.76(3.04)$ & $0.0154(0.87)$ & & \\
\hline XUDEN80 & $2.46(2.02)$ & $-.0167(1.37)$ & & \\
\hline \multicolumn{5}{|l|}{ Endog. Var: } \\
\hline LNRWAG80 & $6.83(0.42)$ & & & $59.96(1.82)^{\prime}$ \\
\hline UDEN80 & $33.9(16.6)$ & $.0023(1.13)$ & $.0120(8.39)^{\mathrm{I}}$ & \\
\hline $\begin{array}{l}\text { Number of } \\
\text { Observations }\end{array}$ & 734 & & & \\
\hline $\mathbf{R}^{2}$ & & 0.55 & 0.45 & 0.56 \\
\hline
\end{tabular}

${ }^{\mathrm{a}}$ Standard Deviation and the absolute values of the White heteroskedastic-consistent t-statistics are in parentheses.

${ }^{\mathrm{I}}$ Significant at a $99 \%$ level.

${ }^{\mathrm{H}}$ Significant at a $95 \%$ level.

'Significant at a $90 \%$ level. 
TABLE 3: 1978 And 1980 Mean Values And Parameter Estimates For The Union Sector ${ }^{\mathrm{a}}$

\begin{tabular}{|c|c|c|c|c|}
\hline & $\begin{array}{c}\text { (1) } \\
\text { MEANS } \\
\text { (STAND. DEV) } \\
\end{array}$ & $\begin{array}{c}(2) \\
\text { OLS WAGE EQ. w/ } \\
\text { UDEN and XUDEN }\end{array}$ & $\begin{array}{c}\text { (3) } \\
\text { 3SLS WAGE } \\
\text { EQUATION } \\
\end{array}$ & $\begin{array}{c}(4) \\
\text { 3SLS UDEN } \\
\text { EQUATION } \\
\end{array}$ \\
\hline \multicolumn{5}{|l|}{ Exog. Var: } \\
\hline CTL78 & $0.120(0.30)$ & $0.2405(2.64)^{\mathrm{I}}$ & $0.2310(2.54)^{\mathrm{I}}$ & $-30.23(2.62)^{I}$ \\
\hline CTK78 & $0.344(0.48)$ & $0.0570(1.11)$ & $0.0797(1.54)$ & $-10.24(1.16)$ \\
\hline HT78 & $0.280(0.43)$ & $0.1965(2.10)^{\mathrm{H}}$ & $0.1990(2.30)^{\mathrm{H}}$ & $-25.75(1.90)^{\mathrm{H}}$ \\
\hline MSH78 & $0.083(0.06)$ & $-2.392(1.74)^{\prime}$ & $0.0821(0.17)$ & $-7.494(0.93)$ \\
\hline XSH78 & $0.071(0.06)$ & $0.4297(0.55)$ & $-.2847(0.48)$ & $33.73(0.32)$ \\
\hline MUDEN80 & $3.14(2.97)$ & $0.0692(2.58)^{\mathrm{I}}$ & & \\
\hline XUDEN80 & $2.05(1.65)$ & $-.6341(3.01)^{I}$ & & \\
\hline CTL80 & $0.12(0.30)$ & $-.0135(0.09)$ & $0.3698(2.88)^{\mathrm{I}}$ & $-31.01(4.33)^{\mathrm{I}}$ \\
\hline CTK80 & $0.33(0.47)$ & 0.0834 (1.39) & $0.0233(0.43)$ & $-1.555(0.44)$ \\
\hline HT80 & $0.26(0.42)$ & $0.1365(1.61)^{\prime}$ & $0.2810(3.07)^{\mathrm{I}}$ & $-21.17(3.78)^{I}$ \\
\hline MSH80 & $0.09(0.08)$ & $-.5176(0.31)$ & $-.4136(0.84)$ & $60.11(1.70)^{\prime}$ \\
\hline XSH80 & $0.09(0.07)$ & $-.0699(0.90)$ & $-.3498(0.79)$ & $9.093(0.27)$ \\
\hline MUDEN80 & $3.14(3.26)$ & $-.0389(1.12)$ & & \\
\hline XUDEN80 & $2.53(2.56)$ & $-.0235(1.24)$ & & \\
\hline \multicolumn{5}{|l|}{ Endog. Var: } \\
\hline LNRWAG78 & $6.92(1.36)$ & & & $128.35(1.92)^{\mathrm{H}}$ \\
\hline UDEN78 & $37.6(18.1)$ & $0.0023(0.84)$ & $.0076(3.57)^{\mathrm{I}}$ & \\
\hline LNRWAG80 & $6.90(0.56)$ & & & $49.41(1.60)^{\prime}$ \\
\hline UDEN80 & $36.9(19.3)$ & $.0013(0.41)$ & $.0121(5.23)^{\mathrm{I}}$ & \\
\hline $\begin{array}{l}\text { Number of } \\
\text { Observations }\end{array}$ & 285 & & & \\
\hline
\end{tabular}

${ }^{a}$ Standard Deviation and the absolute values of the White heteroskedastic-consistent t-statistics are in parentheses.

${ }^{\mathrm{I}}$ Significant at a $99 \%$ level.

${ }^{\mathrm{H}}$ Significant at a $95 \%$ level.

'Significant at a $90 \%$ level. 
TABLE 4: 1978 And 1980 Mean Values And Parameter Estimates For The Nonunion Sector ${ }^{a}$

\begin{tabular}{|c|c|c|c|c|}
\hline & $\begin{array}{c}\text { (1) } \\
\text { MEANS } \\
\text { (STAND. DEV) } \\
\end{array}$ & $\begin{array}{c}\text { (2) } \\
\text { OLS WAGE EQ. w/ } \\
\text { UDEN and XUDEN }\end{array}$ & $\begin{array}{c}\text { (3) } \\
\text { 3SLS WAGE } \\
\text { EQUATION } \\
\end{array}$ & $\begin{array}{c}\text { (4) } \\
\text { 3SLS UDEN } \\
\text { EQUATION } \\
\end{array}$ \\
\hline \multicolumn{5}{|l|}{ Exog. Var: } \\
\hline CTL78 & $0.11(0.27)$ & $-.0695(0.63)$ & $-.2861(2.15)^{\mathrm{H}}$ & $-17.66(6.55)^{\mathrm{I}}$ \\
\hline CTK78 & $0.29(0.45)$ & $0.0055(0.10)$ & $-.0974(1.37)$ & $-8.436(5.34)^{I}$ \\
\hline HT78 & $0.37(0.47)$ & $0.0397(0.51)$ & $-.1188(1.27)$ & $-9.823(4.72)^{I}$ \\
\hline MSH78 & $0.07(0.07)$ & $-.1383(0.14)$ & $1.370(2.51)^{\mathrm{I}}$ & $53.62(4.31)^{\mathrm{I}}$ \\
\hline XSH78 & $0.09(0.07)$ & $0.0621(0.26)$ & $-1.492(1.90)^{\prime}$ & $-118.6(9.63)^{\mathrm{I}}$ \\
\hline MUDEN78 & $2.12(2.27)$ & $0.0154(0.87)$ & & \\
\hline XUDEN78 & $1.90(1.45)$ & $-.3124(1.14)$ & & \\
\hline$\overline{\text { CTL80 }}$ & $0.10(0.28)$ & $-.0426(0.59)$ & $-.0626(0.80)$ & $-8.800(2.87)^{\mathrm{I}}$ \\
\hline CTK80 & $0.27(0.44)$ & $-.0164(0.29)$ & $0.2302(0.45)$ & $-8.074(4.23)^{\mathrm{I}}$ \\
\hline HT800 & $0.24(0.40)$ & $0.0675(0.90)$ & $0.1141(1.54)$ & $-16.13(6.87)^{I}$ \\
\hline MSH80 & $0.07(0.06)$ & $-.9745(1.29)$ & -.3027 (0.84) & $47.35(3.52)^{\mathrm{I}}$ \\
\hline XSH80 & $0.11(0.08)$ & $0.2665(0.99)$ & $0.5638(1.46)$ & $-59.05(4.15)^{I}$ \\
\hline MUDEN80 & $2.04(2.48)$ & $0.0213(1.01)$ & & \\
\hline XUDEN80 & $2.31(2.31)$ & $-.0013(1.37)$ & & \\
\hline \multicolumn{5}{|l|}{ Endog. Var: } \\
\hline LNRWAG78 & $6.83(0.42)$ & & & $-.5540(0.02)$ \\
\hline UNDEN78 & $29.8(16.2)$ & $.0024(0.73)$ & $.0087(1.90)^{\prime}$ & \\
\hline LNRWAG80 & $6.90(0.56)$ & & & $3.759(1.14)$ \\
\hline UDEN80 & $28.8(18.2)$ & $.0023(1.13)$ & $.0058(1.95)^{\mathrm{H}}$ & \\
\hline $\begin{array}{l}\text { Number of } \\
\text { Observations }\end{array}$ & 448 & & & \\
\hline
\end{tabular}

${ }^{a}$ Standard Deviation and the absolute values of the White heteroskedastic-consistent t-statistics are in parentheses.

${ }^{\mathrm{I}}$ Significant at a $99 \%$ level.

${ }^{\mathrm{H}}$ Significant at a $95 \%$ level.

'Significant at a $90 \%$ level. 
Notes 